tude as radar sets are made to produce more and more data required for use operationally.

A chapter on 'angels' shows that argument is still strong on the causes of echoes received from apparently clear air. The book concludes with a chapter on special instrumental techniques, which might well have come at the end of the theoretical section, since some of the techniques are referred to thereafter. There is no doubt that the meteorologist is now developing radar sets to meet his special needs, and we can expect progress to become even more rapid than over the initial fifteen years of radar meteorology covered by this book.

The book is well produced and there are adequate references, although the method of giving references as footnotes, liberally sprinkled with op.cit. and ibid., is at times irritating. The small circle of prospective buyers presumably necessitates the high price.

J. R. Probert-Jones

\section{DELINQUENT BOYS AND THEIR PARENTS}

\section{On the Threshold of Delinquency}

By John Barron Mays. (Social Research Series.) Pp. $\quad x+243$. (Liverpool: Liverpool University Press, 1959.) 25s. net.

\section{Delinquency and Parental Pathology}

A Study in Forensic and Clinical Psychology. By Dr. Robert G. Andry. Pp. xv + 173. (London: Methuen and Co., Ltd., 1960.) 21s. net.

ACH of these books is a study of a small group of E delinquent boys-but they have little else in common. Mr. Mays has written an engaging account of an attempt to deal with a particularly difficult bunch of youngsters by setting up a youth club in a delinquent area. No systematic description is given of what actually went on inside the Dolphin Club and one has only a vague picture, for example, of the number of staff engaged, of the use and misuse of equipment, and what a normal week's programme looked like. But a much more important point is made and illustrated with a wealth of detail, that the Club succeeded in keeping boys off the streets and enlisted the co-operation of otherwise indifferent parents in achieving this and possibly other aims.

There are three main strands running through the work : $(a)$ an account of incidents and activities in and around the club; (b) pen pictures and casehistories of the club members ; (c) many observations on the social patterns of the district and on the nature of delinquency in general.

The book is somewhat discursive, and the author moves rather too freely from one topic to another. But the observation is shrewd, the descriptions are vivid, and the commentary is uncommonly penetrating. The reader's interest is held, and at the end one has a clear picture of a courageous experiment carried out by people who had no illusions but who were not thereby discouraged. Their achievement is clear and the book is both informative and encouraging.

In a particularly discerning passage (pp. 26-28), Mr. Mays gives an overall estimate of the major factors underlying delinquent behaviour in adoles- cents. He brings out clearly the difficulties of "boys approaching adolescence who require a strong father figure with whom they can identify themselves". This is, to a large extent, the text of Dr. Andry's remarkable study. Here eighty delinquent boys in a remand home are compared with eighty non-delinquent boys from a reasonably matched group. Following a systematic interviow of each of these boys and of thirty sets of parents in each group, he examines parental roles as perceived by the boys and also the parents' perception of their own roles. He concludes that delinquent boys "tend to perceive greater defects in their fathers' roles than in their mothers' roles, whereas non-delinquents tend to perceive the roles of both parents as being adequate. (Further, this seems confirmed in the main by both parents)". This general conclusion is followed up by detailed investigation on specific points, and the differential response of the delinquent and nondelinquent is subjected throughout to a statistical test of significance. For the most part the differences between the responses of the delinquent and the nondelinquent group are most impressive.

In his introduction to Dr. Andry's book, Dr. Mannheim implies that some special interest in fathers is a not unexpected reaction to Bowlby's now classic theory of the effects of early maternal depriva. tion. This may be so, but Dr. Andry's study and Dr. Bowlby's work are not strictly comparable. Andry specifically excludes neurotic cases (though he does not define the term) and his technique is confined to questioning adolescent boys (between the ages of 11 and 15 years) and some of their parents. Since he excludes (for perfectly good reasons) children with an $I . Q$. below 80 and also children from broken homes, his sample is by no means representative of the delinquent population. He might, quite probably, obtain similar results from a wider sample. Bowlby claims to have shown a clear connexion between early traumatic maternal deprivation and subsequent maladjustment (not necessarily delinquent). Moreover, a high proportion of the cases in which he is interested could properly be called neurotic or psychopathic. This is not inconsistent with, but is quite different from, assessing the respective roles of father and mother during the adolescent period.

Dr. Andry's book is somewhat repetitive and his language is occasionally obscure (for example, "a research worker may use a set of data to derive a maximal system of control with respect to the end object via the possible decision"). But the experiment which he describes is rigorously planned and his use of statistical methods is judicious. A short review of the literature and an extremely interesting bibliography are included. This is a study which will certainly have a considerable effect on future thinking and its direct implications so far as case work is concerned are obvious.

One striking fact is mentioned by both Mays and Andry. The delinquent boy is often keenly aware of his father's defects, and particularly of the poor relationship between boy and father. Father and mother are equally aware of the situation; and all the parties concerned would like to see it improved (though their tboughts and feelings may be vague and confused). Experience strongly confirms this, and it seems that actual teaching of the basic techniques of father-son relationships-and particularly the overcoming of embarrassment on both sides-is often surprisingly effective. JoHN Gitrins 